\title{
Basque Turtles? Why? \\ Several basic questions are posed by this volume
}

\section{INTRODUCTION}

Why would the Aranzadi Society of Sciences have a two-day special session on marine turtles of the Bay of Biscay and the eastern Atlantic? After all, every year there are dozens of meetings on marine turtles, around the world, in places where these reptiles are well known and for decades have been recognized to be important to the societies and marine environments involved (FRAZIER, 2003). But, since when have marine turtles been important to the Basque?

Why form a North East Atlantic Sea Turtle Group, when in this region these animals are hardly known to the average biologist - much less to the lay public or decision-makers? There are specialist groups that focus on marine turtles in the Mediterranean, NW Atlantic, Caribbean, SW Atlantic, and other regions of the Indian and Pacific Oceans - but why the North East Atlantic?

Why would people travel across the oceans to Basque Country to attend a meeting on marine turtles?

Although such questions may seem simple, almost obvious, they demand answers that are fundamental to understanding not only the natural history of these intriguing chelonians, but also the underpinnings of more basic issues such as how people interact with their environment and the rest of society. In a word: marine turtles are flagship species (Frazier, 2005). Although they are "lowly reptiles", they inspire people of many nations, cultures, religions, ages, and backgrounds to consider human-environmental relations. They promote a sense of responsibility and cooperation that transcends turtles, science, and conservation - reflections that hearten qualities which make people proud of being human.

The publicised objective of the meeting held at the Aquarium de San Sebastián on 14 \& 15 November 2008 was to nurture a better understanding of the ecology of marine turtles, and to promote conservation initiatives, particularly in this geographic area. However, far more was accomplished than raising awareness about marine turtle natural history and conservation, and this is thanks to the fact that an enormous, diverse clientele admires these "charismatic marine megafauna"; and diverse people from many nations are dedicated to the protection of these shared resources, which results in activities that far surpass usual research and conservation programmes.

To begin with, the people of Basque country are not recent arrivals, nor are they new to the sea. Their history, while bordering on the mysterious, spans millennia. Moreover, Basque fishermen are - and long have been - accomplished mariners. For example, the importance of Basque whalers in the north Atlantic, on both the eastern and western shores, is well documented from at least the 14th and 16th centuries, respectively (AGUILAR, 1986). At a time when many Europeans considered the earth to be flat, Basque fishermen were sailing across the Atlantic Ocean and setting up summer fishing camps in present day Ca-

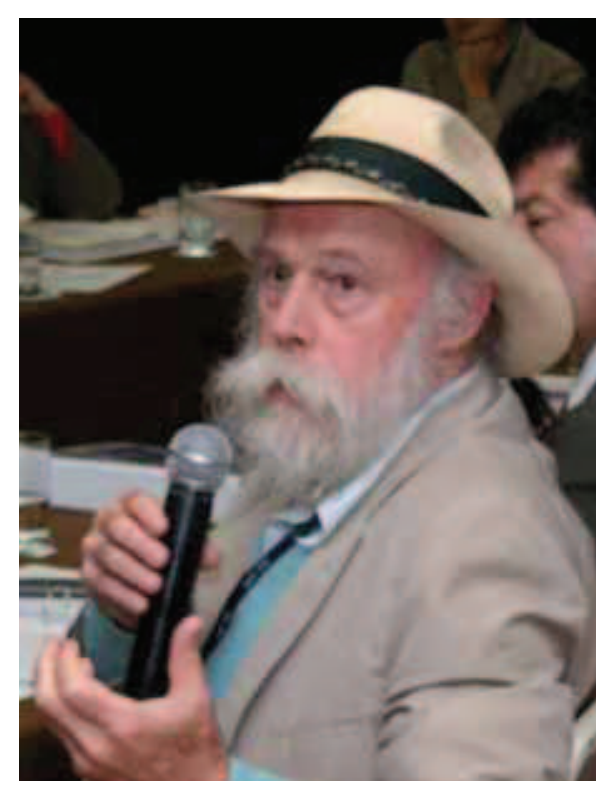

J. Frazier

Department of Vertebrate Zoology Amphibians \& Reptiles,

National Museum of Natural History, Smithsonian Institution kurma@shentel.net

nada, secretly bringing the dried fish back to Europe for sale (KURLANSKY, 1997). Perhaps Basque success in marine matters was too great, for they are attributed with the development of a very effective fishery for north Atlantic right whales, which eventually lead to the virtual extermination of these cetaceans (AGUILAR, 1986). At any rate, there is a long and rich history of Basque peoples and the sea.

By the same token, marine turtles are not unknown in the northeast Atlantic, a fact made abundantly clear by the classic study of Leo BRONGERSMA (1972). After a meticulous revision of literature, both published and unpublished, he reported written records of marine turtles in European waters that date back to the 1300s, as well as scores of written reports of these reptiles in European waters centuries before marine sciences were formerly established. Decades ahead of his time, BRONGERSMA hypothesized that not all marine turtles that occur in European waters are lost, or waifs, but rather that this marine area is part of the normal distribution of some turtles.

Hence, there is every reason to rekindle these historic bases, especially by nurturing a North East Atlantic Sea Turtle Group, and what more appropriate place to do this than in Basque country? For many reasons, the benefits of this effort will be felt far outside the NE Atlantic. An obvious reason why the impacts of north east Atlantic efforts will be widespread is that marine turtles migrate and disperse over vast distances, often crossing ocean basins. 
This migratory characteristic is best known for the leatherback turtle Dermochelys coriacea (Vandelli, 1761), whose situation in the Bay of Biscay and northeast Atlantic has been reviewed by ZALDUA-MENDIZABAL et al. (this volume). Leatherbacks that are found feeding in and migrating through various parts of this region can only have come from other regions. To continue their reproductive cycle, leatherbacks in the NE Atlantic must migrate back to their nesting beaches that are a long way from Europe. Satellite tracking studies on males captured in Nova Scotia, Canada (JAMES et al., 2005; 2007), provide ample evidence of this well-developed migratory phenomenon between feeding grounds in the north western Atlantic and reproductive areas in tropical and subtropical waters of the western Atlantic. Other satellite tracking studies on nesting females in Trinidad (ECKERT, 2006) and Florida, USA (ECKERT et al., 2006) show similar transoceanic movements, often between low latitude tropical and subtropical nesting areas and high latitude, northern Atlantic, waters for feeding. Some females satellite tagged while nesting in Florida, Trinidad, French Guiana, and the Caribbean emigrated eastward across the Atlantic to spend time in the Bay of Biscay as well as in waters off the Azores, Iberian Peninsula, Canary Islands, Cape Verde Islands and Mauritania (ECKERT 2006; ECKERT et al., 2006; FERRAROLI et al., 2002; 2004; HAYs et al., 2004). Earlier studies using flipper tags showed that nesting females tagged in French Guiana were recaptured in Atlantic waters of France and Spain (GIRONDOT \& FRETEY, 1996). Hence, numerous studies, based in different nesting areas, have shown clear links between the north east Atlantic and various parts of the western Atlantic. The case for regular leatherback migrations into the north east Atlantic is further strengthened by records from European Atlantic waters, for example the seasonal occurrence of leatherbacks along the French Atlantic coast (Duguy et al., 2007) and in the Irish Sea (Houghton et al., 2006), where the turtles are commonly observed feeding on jellyfish. In this light, DoYLE et al. (2012) have provided a valuable summary of "jellyfish", their taxonomic, morphological, and ecological characteristics, and how these may relate to leatherback feeding ecology, particularly in the North East Atlantic. Clearly, there is much to learn, but it is clear that by all indications the waters of the north east Atlantic provide important feeding areas for this turtle. P. MoRINIERE's presentation at the San Sebastián meeting (2008) leaves no doubt that leatherbacks have been a regular part of the fauna in French Atlantic waters, at least during two decades from 1988 to 2008, with both males and females recorded, many of adult size; live animals are documented mainly between July and September, and strandings of dead animals peak in October and November. Damage to appendages, especially from fishing gear, and ingested plastics - sometimes in large quantities - were recorded in the majority of animals autopsied.

Loggerhead turtles Caretta caretta (Linnaeus, 1758) are known to make regular circuits around the north Atlantic, from nesting beaches on the south east coast of the USA and the Yucatan Peninsula, Mexico, to feeding and deve- lopmental areas in the north east Atlantic, particularly around the Azores and Madeira (Bolten et al., 1998), where there are regular seasonal occurrences of these turtles. While this conclusion is now widely accepted, it was not given much credence half a century ago when BRONGERSMA (1961) did detailed studies of museum specimens and suggested that loggerhead turtles from the Netherlands come from the western Atlantic. In subsequent research involving compilations and analyses of historic information, he went on to suggest that European Atlantic waters are part of the normal geographic distribution of the loggerhead turtle (BRONGERSMA, 1972). More recent studies add further evidence for regular occurrence of loggerheads in this region. F. DeLL'Amico's presentation during the San Sebastián meeting (2008) shows that this species is a regular part of the fauna along the French Atlantic coast, although annual records have varied greatly between 1988 and 2008. Most reports are between January and April, and adult-sized animals are rare. Damage to front flippers was especially common, and autopsies indicated that ingested plastic occurred in nearly $20 \%$ of the animals.

The situation with green turtles Chelonia mydas (Linnaeus, 1758), Kemp's ridley turtles Lepidochelys kempii (Garman, 1880), and hawksbill turtles Eretmochelys imbricata (Linnaeus, 1766) that occur in European Atlantic waters is less clear. Individuals of these species may be waifs, lost from their respective populations, although there is a possibility that some of them could survive to return to the respective breeding grounds from which they came and reproduce, contributing to the maintenance of their respective populations. BRONGERSMA (1961) concluded that green turtles in Dutch waters had evidently been thrown overboard from ships, and that there were no records from the British Isles. He also BrongERSMA (1961) suggested that ridley turtles found off the coasts of Great Britain and the Netherlands came from the western Atlantic or even from Africa via South America. F. DELL'AmIco's presentation at the San Sebastián meeting (2008) is consistent with these earlier studies. Over the period 1988-2008 only 8 green turtles, and 24 Kemp's ridleys were recorded from the French Atlantic coast. The main period of occurrence was between September and March, and December and April, respectively. With one exception, all animals were of immature size. Hawksbills were not reported from the French Atlantic coast during these two decades.

In summary, the Atlantic coast of Europe does not have nesting beaches for any species of marine turtle, and the Kemp's ridley, green and hawksbill turtles that occur in these waters are likely to be waifs. Nonetheless, the region clearly provides areas critical for the life cycles of leatherback and loggerhead turtles, individuals that come from different nesting areas of the western Atlantic.

The beneficiaries of greater appreciation of, and work on, marine turtles in the north east Atlantic will be far more numerous, diverse, and wide-ranging than just the turtles. Clearly, these marine reptiles - the shared resources between the communities and nations of different parts of the Atlantic basin - will be better off with enhanced understanding and conservation activities in a region that 
is critical to their survival. Additionally, the biologists and conservationists who work in this region will not only have access to more complete, up-to-date information, but they will also find greater collaboration and support from like-minded colleagues who work outside the north east Atlantic region. In turn, researchers and conservationists in other parts of the world will benefit from the experiences, findings, insights, and other work of their colleagues in the north east Atlantic. This is especially true for several specific priorities established by the North East Atlantic Sea Turtle Group which will promote greater worldwide cooperation, namely the creation of a public database, standardization of protocols, enhanced mechanisms of collaboration, and enhanced engagement with diverse sectors outside the marine turtle community. Indeed, depending on how they develop, these regional initiatives could well position the North East Atlantic Sea Turtle Group to take on a global leadership role for marine turtle work.

Important as they are, the points mentioned above still do not contemplate the full importance of nurturing marine turtle work in European Atlantic waters. Because these animals have complex life cycles, the protection of just a single turtle requires adequate management of a wide variety of habitats including beaches, inshore waters, coastal waters, and the high seas - in other words terrestrial, estuarine, benthic, neritic, and pelagic habitats must be considered. Combined with these complex spatial-environmental considerations are challenging temporal issues: a marine turtle may need several decades just to reach maturity, and after that it may need to reproduce for several more decades to increase the chance of making a contribution to the maintenance of its population. Hence, to be effective, research and conservation efforts on marine turtles must be conducted over immense spatial and temporal scales. This approach, the planning and methodologies needed to carry out research and conservation to meet these spatial-temporal demands, present singular challenges: few research horizons are greater than a few years, not to mention the relatively short terms that dominate most political and administrative planning. Promoting true longterm planning and visions is urgently needed - for far more than marine turtle conservation (FRAZIER, 2007; 2010). Any contribution that the design and implementation of marine turtle research and conservation can have toward institutionalising greater temporal and spatial considerations in all aspects of human endeavour would be a major advancement for all kinds of scientific and policy work.

Beyond the local, regional, and global advantages to marine turtle research and conservation, there are other aspects that transcend turtles. Because these animals have intrinsic value - in conservation terms they are "charismatic megafauna" or simply "flagship species" - many diverse objectives can be met by employing the turtles as attentiongetting and validation mechanisms. Research and conservation of north east Atlantic marine turtles requires enhanced understanding of various thematic areas, including: the oceanographic features that affect the dispersion and movements of the turtles, particularly currents (surface and subsurface), temperature, and productivity; the availa- bility in time and space of the turtles' food (e.g., "jellyfish") and predators; issues of marine pollution, particularly temporal and spatial occurrence of plastics and other objects that can be ingested by turtles with fatal consequences; and fisheries activities - season, location, gear types, fishing practices - that pose significant threats to marine turtles. This is not to mention the diverse and complex considerations related to cultural, social, and political issues involving the ways that different people, industries, societies, and nations interact with turtles and their habitats. Understanding these many interacting factors will require integrating the research and planning of many disciplines - a much-lauded goal that has so far been elusive. Once again, promoting and nurturing holistic, integrated approaches to research and management through the design of marine turtle work will have positive ramifications on a wide variety of issues, ranging from specific research to general philosophies of management and policy.

In sum, marine turtles serve not only as attractions for the general public and "oceans ambassadors" but also as stimuli to induce diverse components of different societies to explore more profound reflections on the highly complex interactions between humans and their environments. This leads to a better understanding of the many implications cultural, economic, environmental, historic, political, social, traditional - of our attitudes and actions.

Why Gipuzkoa turtles? To act as human beings, and better understand our role, and act more responsibly.

\section{REFERENCES CITED}

AgUILAR, A. 1986. A review of old Basque whaling and its incidence on the right whales of the North Atlantic. In: Right Whales: Past and Present Status R. L. Brownell Jr., P. B. Best, J. H. Prescott (Eds.): 191-199. Special Issue 10 of the International Whaling Commission. Cambridge, (U.K.)

Bolten, A. B., Bjorndal K. A., Martins, H. R., Dellinger, T., BisColTo, M. J., EncaladA, S. E., Bowen, B. W. 1998. Transatlantic developmental migrations of loggerhead sea turtles demonstrated by mtDNA sequence analysis. Ecol. Appl. 8: 1-7.

BRONGERSMA, L. D. 1961. Notes upon some sea turtles. Zool. Verh. 51: 1-46.

Brongersma, L. D. 1972. European Atlantic Turtles. Zool. Verh. 121. E. J. Brill. Leiden

DelL'Amico, F. 2008. First radio tracking of a young turtle Caretta caretta released fron French atlantic coast. Preliminary results. In: Tortugas marinas en el Golfo de Bizkaia y el Atlántico Oriental, Jornadas técnicas. Donostia-San Sebastián, España. November 2008

Duguy, R., Moriniere, P., Meunier, A. 2007. Observations des tortues marines en 2006 (Golfe de Gascogne). Ann. Soc. Sci. Nat. Charente-Marit.

ECKERT, S. A. 2006. High-use of oceanic areas for Atlantic leatherback sea turtles (Dermochelys coriacea) as identified using satellite telemetered location and dive information. Mar. Biol. 149(5): 1257-1267

Eckert, S. A., Bagley, D., Kubis, S., Ehrhart, L., Johnson, C., SteWART K., DEFREESE, D. 2006. Internesting and postnesting movements and foraging habitats of leatherback sea turtles (Dermochelys coriacea) nesting in Florida. Chelonian Conserv. Biol. 5(2): 239-248. 
Ferraroli, S., Eckert, S., Chevalier, J., Girondot, M., Kelle, L. LEMAHO, Y. 2002. Marine behavior of leatherback turtles nesting in French Guiana for conservation strategy. In: Proceedings of the Twentieth Annual Symposium on Sea Turtle Biology and Conservation. A. Mosier, A. Foley, B. Brost (Compilers): 283284. NOAA Technical Memorandum NMFS-SEFSC-477. Miami.

Ferraroli, S., Georges, J.-Y., Gaspar, P. Lemaho, Y. 2004. Where sea turtles meet fisheries. Nature 429: 521-522.

Frazier, J. 2003. Why do we do this? Mar. Turtle Newsl. 100: 9-15.

Frazier, J. (Ed.) 2005. Marine Turtles as Flagships, Special Issue. MAST 3(2)/4(1). MARE. Amsterdam.

FrAZIER, J. 2007. Sustainable use of wildlife: The view from archaeozoology. J. Nat. Conserv. 15(3): 163-173.

FrazIER, J. 2010. The call of the wild. In: The Archaeology of Anthropogenic Environments. R. M. Dean, (Ed.): 341-369, Center for Archaeological Investigations. Southern Illinois University. Occasional Paper 37

GIRONDOT, M., FRETEY, J. 1996. Leatherback turtles, Dermochelys coriacea, nesting in French Guiana, 1978-1995. Chelonian Conserv. Biol. 2(2): 204-208.
Hays, G. C., Houghton J. D. R., Myers A. E. 2004. Endangered species: Pan-Atlantic leatherback turtle movements. Nature 429: 522.

Houghton, J. D. R., Doyle, T. K., Wilson, M. W., Davenport, J., HAYS, G. C. 2006. Jellyfish aggregations and leatherback turtle foraging patterns in a temperate coastal environment. Ecology 87(8): 1967-1972

James, M. C., Eckert, S. A., Myers, R. A. 2005. Migratory and reproductive movements of male leatherback turtles (Dermochelys coriacea). Mar. Biol. 147: 845-853.

James, M. C., Sherrill-Mix, S. A. Myers, R. A. 2007. Population characteristics and seasonal migrations of leatherback sea turtles at high latitudes. Mar. Ecol. Prog. Ser. 337: 245-254.

KuRLANSKy M. 1997. Cod: A Biography of the Fish that Changed the World. Walker \& Co. New York.

Moriniere, P. 2008. Marine turtles on Atlantic french coast 1988 2008: Activity essessment of the Centre of Study and Care for sea Turtles in Aquarium La Rochelle. In: Tortugas marinas en el Golfo de Bizkaia y el Atlántico Oriental, Jornadas técnicas. Donostia-San Sebastián, España. November 2008. 